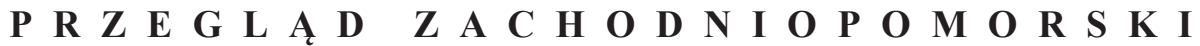 ROCZNIK XXXI (LX) ROK 2016 ZESZYT 3
}

\author{
Malgorzata Machalek, Adam MaKowski*
}

\section{ElekTRyczność w SŁUŻBIE WeAdZY I LUDZI. Elektryfikacja wsi Pomorza Zachodniego W PIERWSZYM ĆWIERĆWIECZU PO DRUGIEJ WOJNIE ŚWIATOWEJ}

Słowa kluczowe: elektryfikacja wsi, Pomorze Zachodnie, wieś

Keywords: electrification of the rural areas, Western Pomerania, villages

\section{Wprowadzenie}

Fascynacja ludzi zjawiskiem elektryczności sięga kultury greckiej, jednak dopiero wiek XIX przyniósł realne próby jej zastosowania w praktyce. Doświadczenia Benjamina Franklina, Charlesa Coulomba, Luigi Galvaniego, Andre Marie Ampera, Georga Ohma, Michaela Faradaya, Wernera von Siemensa, Thomasa Edisona, Pomorzanina - Edwalda Jürgena von Kleista, Hermana Józefa Osińskiego i wielu innych przyczyniły się do powstania urządzeń pozwalających na wykorzystanie energii elektrycznej w gospodarce. Ale dopiero pierwsza połowa XX wieku stała się okresem oswojenia elektryczności w codziennym życiu zwykłych ludzi. Najpierw w najbardziej rozwiniętych krajach Europy i Stanach Zjednoczonych, ale wkrótce w ślad za nimi w Prusach i - dalej - na ziemiach polskich elektryczność powoli stawała się codziennością w przemyśle, urządzeniach komunalnych, a w dalszej kolejności także w domach mieszkalnych.

\footnotetext{
* dr hab. Małgorzata Machałek prof. US, Uniwersytet Szczeciński, Uniwersyteckie Centrum Edukacji, e-mail: malgorzata.machalek@usz.edu.pl; dr hab. Adam Makowski prof. US, Uniwersytet Szczeciński, Wydział Humanistyczny, e-mail: adam.makowski@univ.szczecin.pl.
} 
Studia nad upowszechnianiem zdobyczy techniki, w tym elektryczności, z jednej strony dotyczą wykorzystania ludzkiego geniuszu do rozwoju cywilizacji, a z drugiej - pozwalają na śledzenie zmian społecznych, gospodarczych, a za nimi kulturowych, politycznych, obyczajowych w życiu pojedynczych ludzi i całych narodów. W niniejszym artykule autorzy pragną zwrócić uwagę na dwa aspekty wspomnianych zjawisk. Po drugiej wojnie światowej w Polsce upowszechnienie wykorzystania energii elektrycznej, zwane elektryfikacją wsi, znajdowało wszystkie ze wspomnianych kontekstów. Wpływało na możliwość korzystania z energii elektrycznej w gospodarstwach domowych oraz zastosowania maszyn i urządzeń o napędzie elektrycznym w produkcji rolnej, ale też pozyskiwania poparcia politycznego dla narzuconej Polakom władzy. Jej skutkiem stało się przyspieszone zbliżanie warunków życia ludzi na wsi i w miastach, ale pośrednio, poprzez upowszechnianie dostępu do mediów, także zwiększanie dostępności tych pierwszych do kultury masowej i integracji grup pochodzących z różnych dzielnic i kręgów kulturowych wokół wspólnych wartości narodowych.

Właśnie tym dwóm aspektom poświęcono w niniejszym tekście najwięcej uwagi. Swoje rozważania autorzy zamknęli granicami lat 1945 i 1970. Pierwsza z tych dat wydaje się być naturalna. Kataklizm drugiej wojny światowej przyniósł zmiany polityczne, przesunięcia granic państwa, a za nimi masowe migracje. Z szybkiego awansu cywilizacyjnego nowa władza uczyniła jeden ze swoich głównych celów, a w największym stopniu obszarem tych działań stała się wieś. Z drugiej strony dla znacznej części Polaków zamieszkanie na Ziemiach Odzyskanych oznaczało konieczność zaadaptowania się do - często nowych, nieznanych wcześniej - warunków cywilizacyjnych. Procesy te w największym stopniu widoczne były w pierwszym powojennym ćwierćwieczu. Rok 1970 umownie zamyka procesy integracyjne na ziemiach zachodnich, w dużej mierze sukcesem zakończone zostały zabiegi władzy o upowszechnienie stosowania energii elektrycznej, a pojawienie się nowego pokolenia, nieznającego rzeczywistości przedwojennej, pozwala na stwierdzenie o zamknięciu ważnego okresu w ewolucji cywilizacyjnej Polski.

W tym kontekście nie jest przypadkowy wybór Pomorza Zachodniego jako obszaru objętego refleksją. Po 1945 roku nastąpiła tu niemal całkowita wymiana ludności, a dla osadników przyjeżdżających z ziem wschodniej i centralnej Polski zastane tu warunki techniczne były często nieznanym doświadczeniem. Region miał wybitnie rolniczy charakter, co potęgowała jeszcze powojenna polityka władz Polski, a zastana struktura własności ziemi powodowała, że znacznie 
większy niż na ziemiach dawnych był tu stan posiadania kapitału państwowego i kolektywnego.

Wspomniane zjawiska nie spotkały się dotychczas z większym zainteresowaniem badaczy. W skali ogólnopolskiej problem elektryfikacji wsi był podejmowany wielokrotnie ${ }^{1}$, jednak w kontekście Pomorza Zachodniego problem czeka dopiero na dogłębną analizę². Również niniejszy tekst nie wyczerpuje z pewnością tematu, jest zaledwie przyczynkiem do jego poznania. Bazę dla rozważań stanowią głównie opracowania statystyczne pozwalające na śledzenie postępów analizowanych procesów wzbogacone o badania archiwalne spuścizny zdeponowanej w Archiwum Państwowym w Szczecinie oraz Archiwum Akt Nowych w Warszawie.

\section{Upowszechnianie energii elektrycznej na Pomorzu Zachodnim do drugiej wojny światowej}

Spośród ziem znajdujących się dziś w granicach państwa polskiego Pomorze Zachodnie do drugiej wojny światowej podlegało przeobrażeniom cywilizacyjnym typowym dla wschodnich dzielnic państwa pruskiego. Przełom XIX i XX wieku był czasem wdrażania osiągnięć rewolucji przemysłowej. Warto zaznaczyć, że to właśnie Szczecin w 1889 roku uzyskał pierwszą na ziemiach dzisiejszej Polski własną elektrownię̧3. Dopiero dwa lata później (1891) prąd zaczął płynąć we Wrocławiu, a po kolejnych trzynastu (1904) w Poznaniu 4 .

Tempo upowszechniania elektryczności w Szczecinie było wyższe niż w innych miastach wschodnich Prus i dalszych ziem polskich także w kolejnych latach. Jeszcze przed pierwszą wojną światową w ponad dwukrotnie większym Wrocławiu zużycie energii elektrycznej $(15,5 \mathrm{mln} \mathrm{kWh})$ było nieznacznie tylko

\footnotetext{
${ }^{1}$ Np. S. Chodyna, Zarys dziejów elektryfikacji ziemi ostrołęckiej, „Studia Mazowieckie” 2014, nr 1, s. 9-47; tenże, Dzieje elektryfikacji na ziemi pułtuskiej, „Pułtusk” 2014, t. 10, s. 269-281; B. Górz, Elektryfikacja wsi województwa krakowskiego, Kraków 1964; S. Iwaniak, Elektryfikacja i mechanizacja wsi kieleckiej (1945-1974), „Studia Kieleckie”, Seria Historyczna 1998, nr 3, s. 83-95; S. Krakowiak, Historia elektryfikacji wsi, cz. 1, Warszawa 1997.

2 Jedynym w zasadzie opracowaniem podejmującym problem elektryfikacji Pomorza Zachodniego po II wojnie światowej, w tym także elektryfikacji wsi, jest monografia przygotowana w 2006 r. przez zespół autorów skupionych wokół szczecińskiego oddziału Stowarzyszenia Elektryków Polskich, Elektryka na Pomorzu Zachodnim, red. L. Turek-Kwiatkowska, Szczecin 2006.

${ }^{3} \mathrm{~W}$ tym samym roku elektrownia powstała również w Królewcu.

${ }^{4}$ Historia Kultury Materialnej Polski, t. VI od 1870 do 1918 roku, red. B. Baranowski, J. Bartyś, T. Sobczak, Wrocław-Warszawa-Kraków-Gdańsk 1979, s. 372.
} 
wyższe niż w Szczecinie (13 mln kWh), co oznaczało jego blisko dwukrotnie wyższe zużycie na mieszkańca w stolicy Pomorza Zachodniego. W, nieco mniejszych od Szczecina, Poznaniu i Gdańsku powszechność korzystania z energii elektrycznej była trzykrotnie niższa ${ }^{5}$. Jedynie w Łodzi proces ten przebiegał szybciej.

Tabela 1. Zużycie energii elektrycznej w wybranych miastach w 1912/1913 roku

\begin{tabular}{|l|c|c|c|}
\hline \multicolumn{1}{|c|}{ Miasto } & Liczba ludności & $\begin{array}{c}\text { Zużycie energii } \\
\text { elektrycznej w tys. kWh }\end{array}$ & $\begin{array}{c}\text { Zużycie energii elektrycznej } \\
\text { w przeliczeniu na mieszkańca w kWh }\end{array}$ \\
\hline Warszawa & 830000 & 11000 & 13 \\
\hline Łódź & 475000 & 40000 & 84 \\
\hline Szczecin & 236000 & 13017 & 55 \\
\hline Wrocław & 526000 & 15557 & 19 \\
\hline Gdańsk & 180000 & 3504 & 16 \\
\hline Poznań & 157000 & 2539 & 1918 roku, \\
\hline
\end{tabular}

Źródło: na podstawie: Historia Kultury Materialnej Polski, t. VI od 1870 do 1918 roku, red. B. Baranowski, J. Bartyś, T. Sobczak, Wrocław-Warszawa-Kraków-Gdańsk 1979, s. 372-373.

Stosunkowo szybko następowało oswajanie mieszkańców Szczecina i całego Pomorza Zachodniego z dobrodziejstwami energii elektrycznej ${ }^{6}$. W dużej mierze wynikało to z polityki rządu pruskiego - 12 marca 1912 roku rozpoczęto tam planową elektryfikację całego państwa. O ile w końcu XIX wieku w Szczecinie zaledwie nieco ponad $10 \%$ mieszkańców było odbiorcami energii elektrycznej7, to w 1939 roku, po uruchomieniu nowoczesnej elektrowni cieplnej „Pomorzany" o mocy $200 \mathrm{MW}$, użycie tego medium można już nazwać powszechnym. Poza miastami, sieci energetyczne doprowadzone już były do $86 \%$ gmin regionu. Sieć zasilana była głównie przez elektrownie „Finkenheerd” koło Franfurtu (211 MW), „Szczecin” (86 MW) oraz wspomnianą powyżej „Pomorzany”. Ich uzupełnieniem były siłownie w Białogardzie (24,8 MW), Świnoujściu (3,9 MW), Kołobrzegu (1280 kW) i mniejsze w Goleniowie, Gryfinie, Połczynie i Myśliborzu

\footnotetext{
${ }^{5}$ Por. A. Romanow, Warunki życia ludności Gdańska, w: Historia Gdańska, t. IV/1: 1815-1920, red. E. Cieślak, Sopot 1998, s. 439.

${ }^{6}$ Szerzej por. E. Włodarczyk, Rozwój urbanistyczny miast pomorskich i ich gospodarka komunalna, w: Historia Pomorza, t. IV (1950-1918), cz. I, Ustrój, gospodarka, społeczeństwo, red. S. Salmonowicz, Toruń 2000, s. 471-472

${ }^{7}$ Elektryka na Pomorzu..., s. 34

${ }^{8}$ Trzeci Zjazd Przemystowy Ziem Odzyskanych, 7-9 IX 1947 r., Warszawa-Łódź 1948, s. 91.
} 
(po kilkaset $\mathrm{kW}$ ) oraz około 30 średnich i małych elektrowni wodnych o łącznie zainstalowanej mocy około $25 \mathrm{MW}^{9}$. Wykorzystywały one głównie biegi malowniczych, pomorskich rzek Gwdy, Regi, Drawy, Słupi, Parsęty. Swoje niewielkie elektrownie miały niektóre zakłady przemysłowe.

Stan ten pozwala na stwierdzenie, że u schyłku drugiej wojny światowej energia elektryczna na Pomorzu Zachodnim była w powszechnym lub częstym użyciu zarówno w przemyśle, gospodarce komunalnej, rolnictwie, jak i w gospodarstwach domowych. Istniejącą sieć przesyłową należy również uznać za dobrze rozwiniętą. Zasadniczą jej częścią była linia $100 \mathrm{kV}$, rozgałęziona przez węzły średniego napięcia 40 i $50 \mathrm{kV}$ oraz 10 i $15 \mathrm{kV}$.

Niestety, kataklizm wojenny i późniejsze demontaże prowadzone przez wojska radzieckie spowodowały znaczne uszczuplenie infrastruktury energetycznej. Pomorze Zachodnie straciło zasilanie z elektrowni zaodrzańskiej, zniszczeniu uległ zakład „Pomorzany”, a siłownie „Szczecin” i „Białogard” utraciły ponad połowę swoich mocy. Całkowicie zdemontowana została elektrownia w Świnoujściu i większość nowocześniejszych elektrowni wodnych. Według danych z maja 1945 roku na Pomorzu Zachodnim znajdowały się 4 elektrownie cieplne i 13 wodnych o różnym stopniu dewastacji ${ }^{10}$. Z sieci przesyłowych $100 \mathrm{kV}$ zrujnowana została linia Szczecin-Gorzów, w 40\% zachowała się linia Stargard-Białogard. Mniejsze straty odniosły linie średniego napięcia, choć i tu miejscami pozostało $\mathrm{z}$ nich zaledwie $20 \%$. Większe straty notowano w liniach 10 i $15 \mathrm{kV}$, a całkowicie zrujnowane zostały sieci niskiego napięcia ${ }^{11}$.

\section{Odbudowa potencjału energetycznego Pomorza Zachodniego}

Zniszczenia wojenne i powojenne w praktyce oznaczały znaczne zubożenie cywilizacyjne ziem włączonych do Polski i zmniejszenie ich przewagi w stosunku do ziem dawnych. Widoczne jest to bardzo wyraźnie w stanie elektryfikacji wsi. O ile tuż przed wybuchem wojny na ziemiach polskich z wyłączeniem kresów wschodnich zelektryfikowanych było około $4 \%$ wsi, a na ziemiach pruskich, które w 1945 roku weszły w skład państwa polskiego odsetek ten sięgał 90\%, to po

9 Tamże, s. 91; Elektryka na Pomorzu..., s. 37.

${ }^{10}$ Archiwum Państwowe w Szczecinie (dalej: APSz), Urząd Wojewódzki Szczeciński (dalej: UWS), sygn. 4100, Zakłady wytwórcze Zjednoczenia Energetycznego i ich produkcja w maju [1945], k. 157.

${ }^{11}$ Trzeci Zjazd Przemysłowy..., s. 91-92. 
zakończeniu wojny na tych pierwszych sytuacja nie uległa większej zmianie, a na Ziemiach Odzyskanych swoje połączenia z siecią elektroenergetyczną utrzymało niespełna $20 \% \mathrm{wsi}^{12}$.

Zakończenie działań wojennych stawiało przed nowymi władzami polskimi obowiązek odbudowy kraju oraz integracji Śląska, Ziemi Lubuskiej, Pomorza, Warmii i Mazur z pozostałymi dzielnicami kraju, leżącymi w nowych granicach Polski. W zakresie elektryfikacji oznaczało to szybkie odtworzenia infrastruktury elektroenergetycznej na ziemiach odzyskanych oraz jej rozbudowę na ziemiach dawnych. Realizacja tych zadań odbywała się w całkowicie nowym otoczeniu społeczno-gospodarczym i politycznym, co warunkowało zarówno jej tempo, jak i kierunki działań. Koncentrując się w niniejszym artykule na procesach elektryfikacji wsi, należy podkreślić istotne różnice w strukturze społeczno-gospodarczej wsi w Polsce północnej i zachodniej oraz w pozostałej części kraju. Na Pomorzu Zachodnim do 1945 roku połowę gruntów rolnych obejmowały majątki junkierskie o powierzchni powyżej $100 \mathrm{ha}^{13}$. W Polsce centralnej i południowo-wschodniej dominowały gospodarstwa małe i średnie, co było skutkiem XIX-wiecznych procesów uwłaszczeniowych oraz reformy rolnej wprowadzonej przez Polski Komitet Wyzwolenia Narodowego ${ }^{14}$. Siłą rzeczy różny był potencjał ekonomiczny gospodarstw, ich możliwości inwestycyjne i zapotrzebowanie na energię.

W odniesieniu do Pomorza Zachodniego można mówić o trzech formach elektryfikacji. Pierwszą była reelektryfikacja, czyli uruchomienie przedwojennych elektrowni, odbudowa linii przesyłowych i podłączenie do sieci miejscowości, które miały instalacje elektryczne. Druga forma, to właściwa elektryfikacja - mimo stosunkowo znacznego zaawansowania i rozbudowy sieci energetycznej jednak nie wszystkie wsie były zelektryfikowane. Trzecia forma, to doelektryfikowanie, czyli przyłączenie do sieci energetycznej pojedynczych zagród lub całych miejscowości, najczęściej kolonii, które ze względu na znaczne oddalenie od głównych linii przesyłowych lub niechęć dawniejszych gospodarzy nie zostały

${ }^{12}$ Obliczenia na podstawie: S. Krakowiak, Elektryfikacja wsi, cz. I, Warszawa 1997, s. 7-10.

${ }^{13}$ W. Stępiński, Wieś pomorska $w$ drugiej połowie XIX i na początku XX wieku, w: Historia Pomorza, t. IV (1850-1918)...; H. Schmidt, Die Landwirtschaft von Ostpreussen und Pommern 1914/18-1939, Marburg/Lahn 1978, s. 29.

${ }^{14}$ Dekret Polskiego Komitetu Wyzwolenia Narodowego z 6.09.1944 r. o przeprowadzeniu reformy rolnej, Dz. U. 1944, nr 4, poz. 7. Niewiele w tym zakresie zmienił Dekret z 6.09.1946 r. o ustroju rolnym i osadnictwie na obszarze Ziem Odzyskanych i byłego Wolnego Miasta Gdańska (Dz.U. 1946, nr 49, poz. 279). 
zelektryfikowane przed wojną. Rozwiązanie tego problemu okazało się ogromnym wyzwaniem również dla nowych władz, a wiele zagród nie miało dostępu do elektryczności jeszcze na początku lat 70. XX wieku. Podobnie jak to działo się w innych regionach kraju, również na Pomorzu Zachodnim koncentrowano się przede wszystkim na doprowadzeniu energii elektrycznej do gospodarstw domowych, co zaowocowało pojawieniem się w domach lamp elektrycznych, radioodbiorników, a pod koniec lat 60 . XX wieku - telewizorów. W mniejszym stopniu elektryfikacja wsi wpłynęła na efektywność produkcji rolnej w gospodarstwach indywidualnych. Nieco lepiej przedstawiała się sytuacja w państwowych gospodarstwach rolnych i zakładach przetwórstwa rolnego. Zgodnie z polityką władz były one lepiej wyposażone w maszyny i urządzenia o napędzie elektrycznym i w pierwszej kolejności uzyskiwały dostęp do sieci energetycznej.

Dzięki rozpoczętym już w 1945 roku działaniom związanym z elektryfikacją wsi na obszarach mniej zniszczonych w ciągu kilku lat udało się w zasadzie odbudować infrastrukturę. Przykładem może być powiat koszaliński, gdzie już w 1949 roku 90\% wsi było zelektryfikowane, a do podłączenia pozostało jedynie 15 miejscowości ${ }^{15}$. Na innych terenach sytuacja przedstawiała się jednak znacznie gorzej, np. na części powiatu gryfińskiego w tym samym czasie zniszczonych było jeszcze ok. $40 \%$ linii elektrycznych ${ }^{16}$. Poza oczywistymi ograniczeniami organizacyjnymi i finansowymi jedną z poważnych przyczyn tego stanu rzeczy był brak specjalistów oraz ogromny deficyt w zaopatrzeniu w węgiel. Niezmiernie trudno było zastąpić niemiecki fachowy personel techniczny, a dostawy surowca trzeba było dopiero zorganizować.

Niewątpliwie zaangażowanie kapitału państwowego w przywrócenie do życia zniszczonej oraz budowę nowej infrastruktury energetycznej, ale i włączenie się mieszkańców w te procesy przyczyniły się do bardzo szybkiego uzyskania spektakularnych efektów w postaci odtworzenia stanu przedwojennego. Stan ten w ogólnym zarysie uzyskano już na przełomie lat 40. i 50. XX wieku' ${ }^{17}$.

${ }^{15}$ APSz, UWS, sygn. 4563, Protokół z odbytego posiedzenia Koszalińskiego Komitetu Elektryfikacji Wsi spisany w dniu 26.01.[19]49 r., k. 153.

${ }^{16}$ APSz, UWS, sygn. 4468, Pismo Starostwa Powiatowego w Dębnie do Urzędu Wojewódzkiego Szczecińskiego z 14.03.1950 r., k. 3.

${ }^{17} \mathrm{~W}$ skali kraju proces reelektryfikacji ostatecznie zakończył się dopiero w 1954 r. Elektryfikacja wsi 1950-1959, „Statystyka Polski” 1961, z. 48, s. V. 


\section{Energia elektryczna w służbie ustroju}

Procesy elektryfikacji wsi miały również swój wymiar ustrojowo-polityczny. Do końca drugiej wojny światowej postępy w rozszerzaniu zasięgu dostępu do energii elektrycznej wynikały z ekonomicznej aktywności przedsiębiorstw prywatnych (najczęściej spółek akcyjnych) oraz komunalnych, zdecydowanie rzadziej zaś - kapitału państwowego. Pierwsze działania wspierające przedsiębiorstwa związane z rozwojem energetyki podjęto jeszcze w okresie międzywojennym. W 1933 roku prezydent RP wydał rozporządzenie w sprawie popierania elektryfikacji ${ }^{18}$, zgodnie z którym wprowadzono wiele ulg i przywilejów dla firm inwestujących w rozwój elektrowni lub linii przesyłowych. Działania te nie przyniosły jednak zasadniczego przełomu w upowszechnianiu wykorzystania tej formy energii, a państwo zachowało bardziej funkcję propagatora niż aktywnego realizatora idei elektryfikacji.

Sytuacja uległa zmianie wraz z przeobrażeniami politycznymi po zakończeniu wojny. W wyniku nacjonalizacji znacznej części własności gospodarczej, w tym wszystkich większych elektrowni, kluczowym decydentem na rynku energetyki stało się państwo. Jedynie w ciągu kilku pierwszych powojennych lat w procesach tych uczestniczył kapitał prywatny. O roli, jaką władze przypisywały rozwojowi energetyki świadczy też jej wysokie usytuowanie w strukturach rządowych. Początkowo, po 1944 roku, energetyka leżała w zakresie zadań Ministra Przemysłu (następnie Przemysłu i Handlu). Ale już 10 lutego 1949 roku, w okresie przygotowań do realizacji planu sześcioletniego, stworzono Ministerstwo Górnictwa i Energetyki (w okresie 7.03.1950-15.02.1952 r. Ministerstwo Górnictwa), a 15 lutego 1952 roku wyodrębniono z niego osobne Ministerstwo Energetyki, które odpowiadało za wykonanie najważniejszych zadań w okresie realizacji programu elektryfikacji wsi.

Umiejscowienie energetyki w strukturach rządowych uległo nieznacznym tylko zmianom w kolejnych dekadach istnienia PRL. Po przełomie październikowym 1956 roku i zmniejszeniu rozmiarów administracji centralnej, ponownie doszło do połączenia ministerstw Górnictwa i Energetyki w resort Górnictwa i Energetyki. Rangę ministerstwa, w okresie od 23 grudnia 1970 roku do 4 września 1974 roku, podnosiło to, że jego kierownik, Jan Mitręga, pełnił dodatkowo funkcję wicepremiera. Zainteresowanie energią atomową w dekadzie rządów

\footnotetext{
${ }^{18}$ Rozporządzenie Prezydenta RP z 27.10.1933 r. w sprawie popierania elektryfikacji. Dz.U. nr 85, poz. 633 .
} 
Edwarda Gierka skutkowało powołaniem 27 marca 1976 roku Ministerstwa Energetyki i Energii Atomowej, następnie, 3 lipca 1981 roku ponowne połączonego z Ministerstwem Górnictwa w resort Górnictwa i Energetyki. Kierował nim jeden z najbliższych współpracownika gen. Wojciecha Jaruzelskiego - gen. Czesław Piotrowski. Stan taki istniał do 23 października 1987 roku, kiedy to energetykę podporządkowano Ministerstwu Przemysłu.

Powojenne władze, importując leninowską tezę mówiącą, że „Komunizm to władza sowiecka plus elektryfikacja całego kraju", uznały elektryfikację wsi za jedno ze swoich sztandarowych przedsięwzięć. Postawa taka wynikała z przesłanek ekonomicznych i politycznych. Władze zdawały sobie sprawę, że szybkie upowszechnienie energii elektrycznej pomoże poprawić wyniki produkcyjne w rolnictwie, co wobec katastrofalnego poziomu zaopatrzenia kraju w żywność miało ogromne znaczenie. Spodziewano się, że elektryfikacja wsi przyczyni się do zrównania poziomu życia mieszkańców wsi i miast, co miało być dowodem awansu cywilizacyjnego tych pierwszych. Wzgląd na ten ostatni argument dawał nowej władzy również atuty polityczne. Demonstrowanie troski o poprawę warunków życia mieszkańców wsi pozwalało bowiem wskazywać na różnice w polityce nowych władz i jej sanacyjnych odpowiedników. W ten sposób władza chciała zapewnić poparcie sobie i rozpoczynającym się socjalistycznym przemianom ustrojowym na wsi.

Kolejnym, nie mniej ważnym argumentem, była potrzeba dotarcia do mieszkańców wsi z przekazem propagandowym. Radio (głośnik) było bezpośrednio po wojnie jednym z najskuteczniejszych środków oddziaływania na świadomość społeczeństwa. Aby zapewnić temu medium odpowiednią skuteczność, konieczne było doprowadzenie sieci energetycznej do każdego gospodarstwa domowe$\mathrm{go}^{19}$. O wadze politycznego aspektu świadczy to, że w rzeczywistości o kolejności przyłączania poszczególnych wsi czy gromad do sieci energetycznej decydowały nie względy logistyczne, finansowe czy techniczne a właśnie polityczne. W pierwszej kolejności elektryfikowane były państwowe gospodarstwa rolne, a od 1948 roku wsie, w których zostały zawiązane spółdzielnie produkcyjne ${ }^{20}$.

${ }^{19}$ Archiwum Ant Nowych (dalej: AAN), Ministerstwo Rolnictwa i Reform Rolnych (dalej: MRiRR), sygn. 1707, Sprawozdanie z konferencji w sprawie „Elektryfikacji i radiofonizacji wsi”, która odbyła się 26.08.1946 r., bp.

${ }^{20}$ APSz, UWS, sygn. 4563, Protokół z posiedzenia Powiatowego Komitetu Elektryfikacji Wsi w Gryfinie odbytego 20.04.[19]49 r., k. 121. 
Wstępne projekty powszechnej elektryfikacji wsi sformułowano już w 1945 roku, a w wytycznych do realizacji planu trzyletniego (1947-1949) zostało przewidzianych do zelektryfikowania $2500 \mathrm{wsi}^{21}$. Przewidywano wzrost produkcji energii elektrycznej o blisko 50\% (z 5,7 do 8,4 mld kWh)22. Zamierzenie to zostało zrealizowane z nadwyżką ponad 50\% - zostało zelektryfikowanych 3908 wsi. Oznacza to, że z tego medium korzystało wówczas $28,6 \%$ polskich wsi. Wymiar sukcesu pomniejszał nieco fakt, że w związku z koniecznością współfinansowania budowy linii przesyłowych przez mieszkańców nie wszystkie zagrody chłopskie w podłączanych wsiach zostały włączone do sieci. Na koniec lat 40 . XX wieku szacowano, że 409 tys. zagród chłopskich (14,1\%) korzystało z energii elektrycznej23. Tempo tego wzrostu w dużej mierze wynikało z włączenia do statystyk Ziem Odzyskanych, gdzie szybko postępował proces reelektryfikacji dzięki odbudowie zniszczonej infrastruktury.

Zasadniczy postęp w procesie elektryfikacji wsi miał przynieść plan sześcioletni na lata 1950-1955. Zawarta w nim strategia przekształcenia Polski w państwo uprzemysłowione na wsi znalazła między innymi wyraz w postaci przyspieszenia procesów upowszechniania stosowania energii elektrycznej ${ }^{24}$. Przewidywano wzrost produkcji tej formy energii o $237 \%$ oraz elektryfikację 8900 gromad $^{25}$. Projekty te znalazły swoje dodatkowe umocowanie prawne w specjalnej ustawie. Uchwalona na trzy tygodnie przed planem sześcioletnim Ustawa o powszechnej elektryfikacji wsi i osiedli (28.06.1950 r. $)^{26}$ zapowiadała znaczny wysiłek inwestycyjny państwa w tym zakresie, a na mieszkańców nakładała obowiązek częściowego pokrycia kosztów elektryfikacji w postaci opłaty elektryfikacyjnej. W celu sprawowania społecznej kontroli nad elektryfikacją oraz opiniowania projektów miejscowych planów elektryfikacji, prezydia wojewódzkich i powiatowych rad narodowych zostały zobowiązane do powołania komisji elektryfikacji na poziomie województwa, powiatu oraz gromady (art. 6). Przy tworzeniu komitetów obowiązywał klucz partyjny.

${ }^{21}$ AAN, MRiRR, sygn. 1707, Wytyczne w sprawie realizacji elektryfikacji w Polsce, bp.; Elektryfikacja Polski w Planie 6-letnim 1950-1955, Warszawa 1951, s. 30.

${ }^{22}$ Ustawa z 2.07.1947 r. o Planie Odbudowy Gospodarczej, Dz.U. z 1947, nr 53, poz. 285.

${ }^{23}$ Rocznik Statystyczny GUS 1950, Warszawa 1951.

${ }^{24}$ AAN, Centralny Urząd Planowania, sygn. 4290, 6-letni Pan Elektryfikacji Wsi, bp.

${ }^{25}$ Ustawa z 21.07.1950 r. o 6-letnim planie rozwoju gospodarczego i budowy podstaw socjalizmu na lata 1950-1955, Dz.U. 1950, nr 37, poz. 344.

${ }^{26}$ Ustawa z 28.06.1950 r. o powszechnej elektryfikacji wsi i osiedli, Dz.U. 28, poz. 256. 
Dominującą rolę w realizacji ustawy przypisano zjednoczeniom energetycznym, które odpowiadały za przeprowadzenie specjalistycznych robót technicznych, natomiast zapewnienie realizacji prac prostych, dostarczenia podwód, kwater dla wykwalifikowanego personelu oraz pomieszczeń na sprzęt i materiały należało do prezydiów gminnych rad narodowych. Te ostatnie mogły zobowiązać do odpowiednich świadczeń wszystkich mieszkańców wsi ${ }^{27}$.

Koszt inwestycji, w części dotyczącej opracowania dokumentacji projektowej oraz robót elektromontażowych, pokrywały przedsiębiorstwa elektryfikacji rolnictwa, zaś prac instalacyjnych - przyszli użytkownicy. Wysokość opłaty ponoszonej przez mieszkańców ustalono w zależności od dochodu szacunkowego $\mathrm{z}$ gospodarstwa $\mathrm{w}$ drugim roku poprzedzającym rok, w którym zgłoszono instalację do podłączenia ${ }^{28}$. W praktyce opłata stanowiła około $2 / 3$ całości kosztów związanych z elektryfikacją gospodarstwa.

Przyszłość pokazała, że plany te daleko odbiegały od rzeczywistości. Chaos gospodarczy w okresie realizacji planu sześcioletniego bezpośrednio przełożył się również na wyniki w interesującym nas obszarze. Były one dość znaczne, jednak dalekie od planowanych. Zamiast 8900 zelektryfikowanych wsi postęp uzyskano w przypadku niespełna 3500. Zwiększyło to odsetek gromad z dostępem do energii elektrycznej z 28,6 do 38,3\%. Z planowanych 19,3 mld kWh w końcu 1955 roku produkcja zamknęła się kwotą $17,75 \mathrm{mld} \mathrm{kWh}^{29}$.

Na tym tle dość szczególnie przedstawiała się sytuacja na Pomorzu Zachodnim. Część nowych mieszkańców wsi, która przybyła z terenów zabużańskich z trudem dostosowywała się do nowych warunków gospodarowania, dość wolno przekonując się do stosowania maszyn i urządzeń rolniczych. Znacznie szybciej aklimatyzowali się, przyzwyczajeni do mechanizacji, osadnicy z terenów Wielkopolski i Pomorza ${ }^{30}$. Z punktu widzenia nowej polityki społecznej i gospodarczej na wsi rządzącym zależało, by na tym terenie szybko wprowadzać nowe koncep-

\footnotetext{
${ }^{27}$ Rozporządzenie Ministrów Przemysłu Ciężkiego i Finansów z 29.09.1950 r. w sprawie świadczeń osobistych i rzeczowych na cele powszechnej elektryfikacji wsi i osiedli, Dz.U. 1950, nr 45, poz. 420 .

${ }^{28}$ Uchwała nr 480 Rady Ministrów z 14.12.1959 r. w sprawie opłat elektryfikacyjnych pobieranych przy powszechnej elektryfikacji wsi i osiedli, M. P. 1959, nr 103, poz. 554.

${ }^{29}$ Rocznik statystyczny GUS 1956, Warszawa 1956.

${ }^{30}$ A. Kwilecki, Z badań nad przemianami społeczno-kulturowymi wsi na ziemiach zachodnich, „Przegląd Zachodni” 1961, nr 1, s. 112-113; D. Jarosz, Zróżnicowanie kulturowe a zachowania spoteczne w PRL (Prolegomena do badań), w: Kultura wysoka, kultura popularna, kultura codzienności w Polsce 1944-1989, red. G. Miernik, Kielce 2010, s. 146.
} 
cje. $Z$ jednej strony istniała potrzeba udowodnienia światu sukcesów w zagospodarowaniu i integracji nowych ziem, z drugiej zaś niemal całkowita powojenna wymiana ludności stwarzała okazję do wdrażania eksperymentów społecznych i gospodarczych szybciej i łatwiej niż na terenach o silnym przywiązaniu mieszkańców do tradycyjnych struktur społeczno-gospodarczych. Pomorze Zachodnie mogło być swoistym laboratorium stosowania nowych metod gospodarczych i założeń ustrojowych

Znacznie większe niż na ziemiach dawnych zaawansowanie w upowszechnianiu korzystania z urządzeń elektrycznych sprawiało, że łatwiejsze było tu osiąganie założonych celów. Sprzyjającą okolicznością był dodatkowo to, że na bazie poniemieckich majątków ziemskich utworzono państwowe gospodarstwa rolne, które w szczytowym okresie swej działalności użytkowały nawet 50\% areału gruntów rolnych. Na ziemiach dawnych odsetek ziemi w ręku państwa nie przekraczał $15 \%{ }^{31}$. Na początku lat 50 . XX wieku znacząco wyższy niż na ziemiach dawnych był też wskaźnik powstawania spółdzielni produkcyjnych ${ }^{32}$. Dobra sytuacja wyjściowa oraz dodatkowe środki, jakimi gospodarstwa państwowe dysponowały na elektryfikację umożliwiły nie tylko ich szybką reelektryfikację, ale również podniesienie poziomu mechanizacji. Miała świadczyć o nowoczesności i wyższości gospodarki państwowej, ale warto również zwrócić uwagę na to, że stosunkowo słabe zaludnienie wsi na Pomorzu Zachodnim (w 1949 r. wskaźnik zaludnienia wynosił 32 osoby na $100 \mathrm{~km}^{2}$, co stanowiło 61\% stanu z 1939 r.; wskaźnik ogólnopolski wynosił w tym czasie 78 osób na $\mathrm{km}^{2}$ ) wymuszało jak najwyższą mechanizację prac w rolnictwie ${ }^{33}$.

Gorzej przedstawiała się sytuacja rolników indywidualnych, którzy musieli ponieść wysokie koszty przyłączenia ich gospodarstw do sieci energetycznej, ale ten wysiłek początkowo nie przekładał się na unowocześnienie gospodarki. Liczba gniazdek umożliwiających podłączanie maszyn i urządzeń była ograniczona,

${ }^{31}$ Rocznik statystyczny GUS 1979; Rocznik statyczny GUS 1984; J. Skodlarski, Zarys historii gospodarczej Polski, Warszawa 2007, s. 444.

${ }^{32}$ D. Jarosz, Polityka władz komunistycznych w Polsce a chłopi, Warszawa 1998, s. 109; A. Makowski, Pomorze Zachodnie w polityce gospodarczej Polski w latach 1950-1960, Szczecin 2006, s. 119.

${ }^{33}$ T. Białecki, A. Wojtaszak, Osadnictwo polskie jako element procesów migracyjnych na Pomorzu Zachodnim w latach 1945-1948, w: Osadnictwo polskie jako element procesów migracyjnych na Pomorzu Zachodnim w latach 1945-1950. Mity i rzeczywistość, cz. I, red. K. Kozłowski, Szczecin 2002, s. 24; S. Łach, Rolnictwo na Pomorzu Zachodnim w latach 1945-1949, Słupsk 1985, s. 37. 
a w większości gospodarstw brakowało maszyn i urządzeń rolniczych. Spora ich liczba została w latach 1947-1948 odebrana rolnikom i przekazana do powstających wówczas Państwowych Ośrodków Maszynowych. Przynajmniej do lat 60 . $\mathrm{XX}$ wieku rolnicy indywidualni mieli utrudniony dostęp do zakupu nowych maszyn. Swego rodzaju paradoksem jest, że mimo stosunkowo niskiego nasycenia wsi urządzeniami i maszynami, w tym również sprzętem elektrycznym, szybko pojawiły się trudności z pokryciem rosnącego zapotrzebowania na energię elektryczną. Już na początku 1949 roku władze apelowały do rolników, aby nadmiernie „nie obciążali używaniem motorów linii elektrycznej” ${ }^{34}$.

Mimo wspomnianych trudności należy dostrzec wyraźne przyspieszenie, jakie nastąpiło w powszechności korzystania z energii elektrycznej w okresie realizacji planu sześcioletniego. Odsetek zelektryfikowanych wsi znacząco przekraczał na Pomorzu Zachodnim 90\%. Większe od przeciętego było w związku z tym średnie zużycie energii elektrycznej na mieszkańca. Różnica ta w 1956 roku sięgała ponad 50\% (odpowiednio 15,5 i 23,6 kWh na osobę) ${ }^{35}$, interesujące jest, że w miastach sytuacja była odwrotna - ich mieszkańcy na Pomorzu Zachodnim zużywali mniej energii elektrycznej niż w całej Polsce. Wynikało to zapewne z dużego stopnia zniszczeń, jakie dotknęły miasta północno-zachodniej Polski oraz utrzymującej się stagnacji w ich rozwoju.

\section{Mała stabilizacja}

Porażka planu sześcioletniego nie oznaczała wycofania się państwa z polityki elektryfikacji. Wręcz przeciwnie - korekty strategii gospodarczej w niewielkim stopniu dotyczyły produkcji i dystrybucji energii elektrycznej. Po 1956 roku rząd nadal był inspiratorem szeregu prac nad tym zagadnieniem, zarówno w wymiarze teoretycznym, jak i praktycznym.

$\mathrm{W}$ pierwszej połowie lat 60 . XX wieku zelektryfikowano w zasadzie wszystkie państwowe i spółdzielcze gospodarstwa rolne oraz 74\% zagród chłopskich (1965 r.). Odtąd głównym celem elektryfikacji była modernizacja istniejących sieci przesyłowych, podłączanie do sieci nowych obiektów oraz przysiółków o rozproszonej zabudowie i pojedynczych zagród ${ }^{36}$. Rosło też zapotrzebowanie

\footnotetext{
${ }^{34}$ APSz, UWS, sygn. 4563, Protokół z odbytego posiedzenia Koszalińskiego Komitetu Elektryfikacji Wsi spisany 26.01.[19]49 r., k. 155.

${ }^{35}$ Rocznik Statystyczny GUS 1957, Warszawa 1957.

${ }^{36}$ S. Krakowiak, Elektryfikacja wsi, cz. I, Warszawa 1997, s. 22.
} 
gospodarstw państwowych i indywidualnych na energię elektryczną, co powodowało konieczność rozbudowy sieci linii wysokiego napięcia.

W latach 1959-1962 wydano kolejnych pięć aktów prawnych regulujących zakres zakładania na wsiach urządzeń odbiorczych oraz opłat z tym związanych $^{37}$. W formie mniej spektakularnej niż w latach wcześniejszych, ale za to z większymi praktycznymi efektami realizowano akcję elektryfikacji w kolejnej dekadzie. Widoczne przy tym jest szybkie zrównywanie dostępności do energii elektrycznej na nowych i dawnych ziemiach Polski. O ile używanie urządzeń elektrycznych w miastach było powszechne, niezależnie od regionu, to na wsi zmniejszanie różnic w tym zakresie następowało szczególnie wyraźnie w latach 1956-1970. Jeszcze w połowie lat 50. XX wieku na Pomorzu Zachodnim z urządzeń elektrycznych korzystało blisko 95\% gospodarstw, a w skali ogólnopolskiej dotyczyło to co drugiego gospodarstwa. W końcu lat 60 . XX wieku wskaźnik ten na Zachodzie Polski wynosił 100\%, a w całej Polsce przekroczył już 90\%. Szczegółowe tendencje zmian pokazano na rysunku 1.

Ciekawym zjawiskiem są utrzymujące się dłuższy czas różnice w stopniu wykorzystywania urządzeń elektrycznych przez mieszkańców nowych i dawnych dzielnic kraju. Na Pomorzu Zachodnim od połowy lat 50. XX wieku (a więc od momentu, w którym zaczęto prowadzić szczegółowe obliczenia w tym zakresie) utrzymuje się wyraźnie większe zużycie energii elektrycznej w codziennym życiu przez statystycznego mieszkańca wsi przy mniejszym jego wymiarze w przypadku mieszkańców miast. Świadczy to o stosunkowo szybkiej adaptacji nowych mieszkańców wsi Pomorza Zachodniego do istniejącej tam infrastruktury technicznej i wykorzystywaniu jej w większym stopniu niż w przypadku mieszkańców pozostałych regionów kraju. W przypadku miast można tłumaczyć to zjawisko gorszym statusem materialnym ich mieszkańców na Pomorzu Zachodnim.

${ }^{37}$ Zarządzenie Ministra Rolnictwa z 8.05.1959 r. w sprawie zakresu zakładania urządzeń odbiorczych w budynkach objętych powszechną elektryfikacją wsi i osiedli, M.P. 1959, nr 72, poz. 382; Uchwała nr 480 Rady Ministrów z 14.12.1959 r. w sprawie opłat elektryfikacyjnych pobieranych przy powszechnej elektryfikacji wsi i osiedli, M.P. 1959, nr 103, poz. 554; Uchwała nr 304 Rady Ministrów z 8.08.1961 r. zmieniająca uchwałę nr 480 z dnia 14.12.1959 r. w sprawie opłat elektryfikacyjnych pobieranych przy powszechnej elektryfikacji wsi i osiedli, M.P. 1961, nr 63, poz. 272; Uchwała nr 135 Rady Ministrów z 11.04 .1962 r. zmieniająca uchwałę w sprawie opłat elektryfikacyjnych pobieranych przy powszechnej elektryfikacji wsi i osiedli, M.P. 1962, nr 35, poz. 164; Zarządzenie Ministra Rolnictwa z 17.04.1962 r. zmieniające zarządzenie w sprawie zakresu zakładania urządzeń odbiorczych w budynkach objętych powszechną elektryfikacją wsi i osiedli, M.P. 1962, nr 35, poz. 172. 


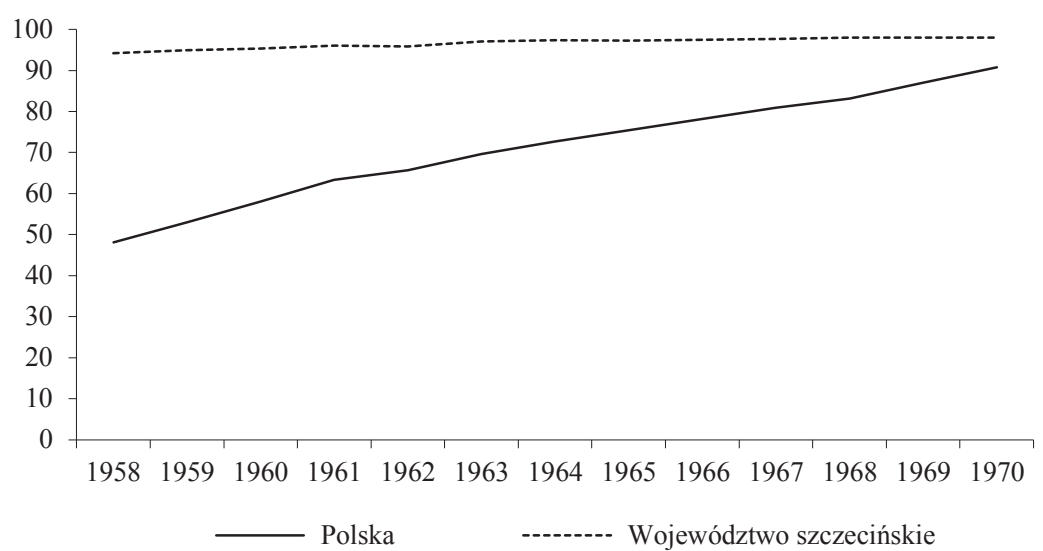

Rysunek 1. Odsetek zelektryfikowanych gospodarstw rolnych w Polsce i województwie szczecińskim w latach 1958-1970

Źródło: Roczniki Statystyczne GUS 1959-1971, Warszawa 1959-1971; Roczniki Statystyczne Województwa Szczecińskiego 1958-1971, Szczecin 1959-1971.

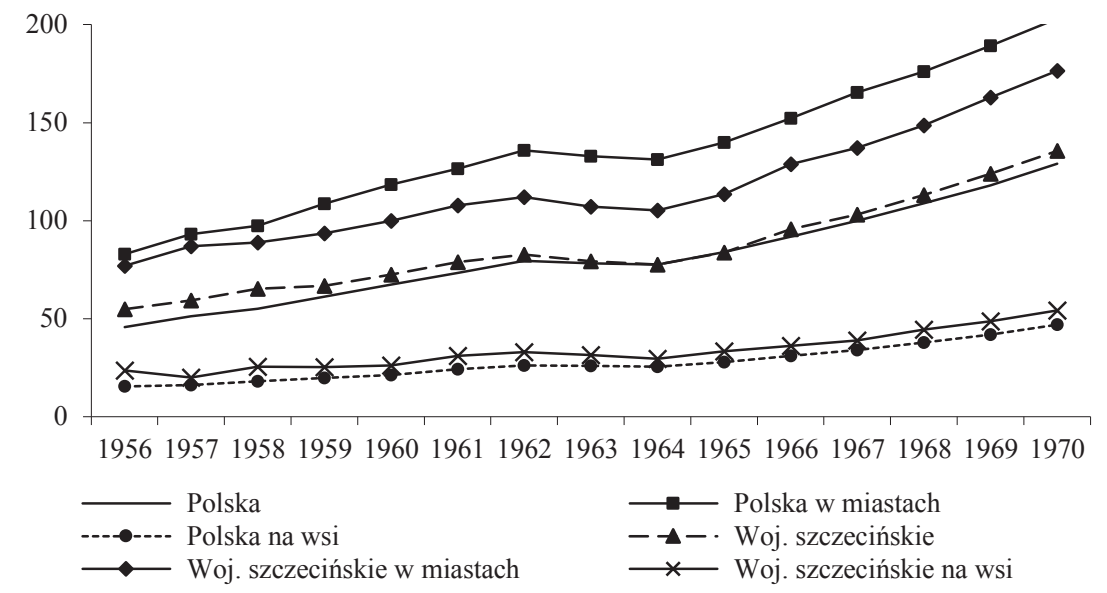

Rysunek 2. Zużycie energii elektrycznej w kWh na mieszkańca w Polsce i w województwie szczecińskim w miastach i na wsi w latach 1956-1970 Źródło: jak pod rys. 1. 


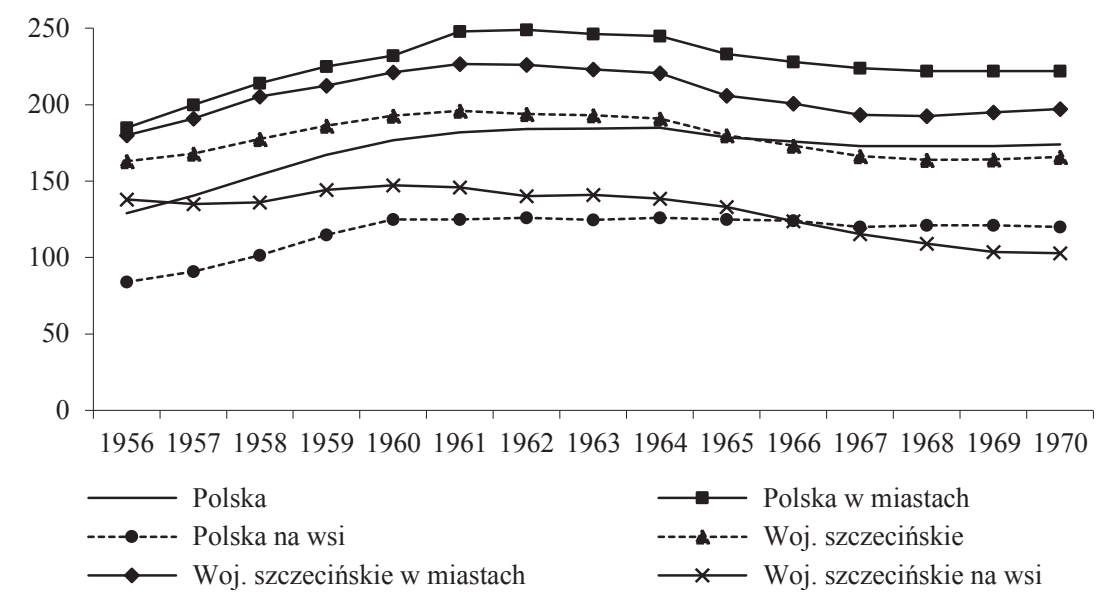

Rysunek 3. Abonenci radiowi na 1000 mieszkańców w Polsce i województwie szczecińskim w miastach i na wsi w latach 1956-1970 Źródło: jak pod rys. 1.

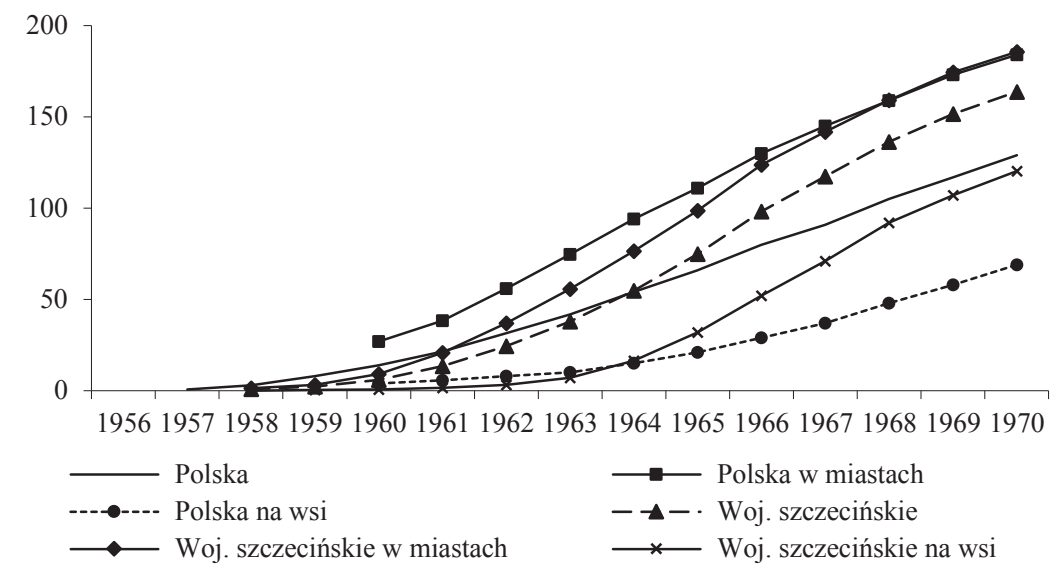

Rysunek 4. Abonenci telewizyjni na 1000 mieszkańców w Polsce i województwie szczecińskim w miastach i na wsi w latach 1956-1970 Źródło: jak pod rys. 1. 
Niższy niż w Polsce centralnej poziom dochodów, regres mniejszych miejscowości ${ }^{38}$, stanowiących zdecydowaną większość w regionie, powodowały również mniejszą dostępność urządzeń elektrycznych, mimo powszechności ich źródła zasilania. Stan ten nie ulegał większym zmianom przez cały badany okres. Dopiero na początku XXI wieku wskaźniki dotyczące wsi wyrównały się przy utrzymującym się niższym ich poziomie w miastach.

Interesującym symptomem powyższego zjawiska jest upowszechnianie niektórych zdobyczy cywilizacyjnych zależnych od zasilania energią elektryczną. Szczególnie skrupulatnie przez cały okres powojenny monitorowane były postępy wzrostu liczby abonentów radiowych i telewizyjnych. Wskaźniki te wykazują zadziwiającą zbieżność $\mathrm{z}$ tendencjami w użyciu energii elektrycznej. W obu przypadkach miasta zachodniopomorskie mają słabsze wskaźniki niż przeciętne w Polsce, a w okresie upowszechniania obu mediów (dla radia jest to okres do 1966 r., dla telewizji po 1964 r.) wieś zachodniopomorska wyraźnie dominuje nad resztą kraju. Warto jednak pamiętać, że obowiązywała prawidłowość, iż szybciej i na większą skalę sprzęty te pojawiały się w domach pracowników PGR-ów niż w domach rolników indywidualnych ${ }^{39}$. Na marginesie warto zastanowić się, na ile ta większa dostępność mediów na wsi zachodniopomorskiej przekładała się na sprzyjające władzy postawy polityczne ich mieszkańców. Wszak oddziaływanie propagandowe było jednym z głównych motywów angażowania państwa w upowszechnianie radia i telewizji. Zadanie to wykracza jednak poza cele niniejszego tekstu.

\section{Podsumowanie}

Przedstawione powyżej procesy elektryfikacji wsi na Pomorzu Zachodnim w pierwszym powojennym ćwierćwieczu wskazują na kluczowe znaczenie państwa w procesie przywracania do życia istniejącej do 1945 roku infrastruktury energetycznej, a następnie jej rozwoju. Dominująca w opisywanym okresie gospodarka planowa pozwalała wprząc to zjawisko w politykę władz państwowych, przynosząc konsekwencje zarówno gospodarcze, jak i polityczne. Poza zamiarem

${ }^{38}$ AAN, Towarzystwo Rozwoju Ziem Zachodnich, sygn. 990, Zatrudnienie wg wysokości zarobku miesięcznego, IX 1956 r., APSz, Prezydium Wojewódzkiej Rady Narodowej w Szczecinie, sygn. 1626, Wstępne koncepcje rozwoju i zagospodarowania województw w latach 1961-1975. Region nadmorski, I 1959 r.

${ }^{39}$ M. Grzybowska, Poziom bytowy pracowników PGR (na podstawie 15 PGR badanych w 1969 r.), Warszawa 1972, s. 24-29. 
autorów pozostały inne, nie mniej znaczące zmiany w życiu mieszkańców wsi spowodowane upowszechnieniem korzystania $\mathrm{z}$ energii elektrycznej. Można śmiało stwierdzić, że elektryfikacja wpłynęła również poważnie na zmianę stylu życia mieszkańców wsi. Oświetlenie elektryczne znacząco wydłużyło okres dziennej aktywności ludzi umożliwiając im dłuższą pracę, rozrywkę lub naukę. Wspomniane wyżej urządzenia elektryczne ułatwiały wykonywanie licznych czynności w gospodarstwie rolnym oraz w domu. Zmiany odczuły kobiety, które dzięki żelazkom elektrycznym, pralkom i lodówkom miały znacznie więcej czasu dla siebie lub na inne aktywności. Oświetlenie elektryczne umożliwiało również organizowanie na wsi życia kulturalnego, zwłaszcza w okresie zimowym, nieco wolniejszym od prac w gospodarstwie. Standardowym wyposażeniem świetlic wiejskich były radia, a z biegiem czasu również gramofony, przy których organizowano zabawy. Do zelektryfikowanych wsi przyjeżdżały kina objazdowe i ekipy Artosu z różnego rodzaju występami artystycznymi ${ }^{40}$. W latach 60 . XX wieku życie towarzyskie na wsiach koncentrowało się wokół pierwszych telewizorów, jakie pojawiły się w klubokawiarniach ${ }^{41}$. Szybko jednak odbiorniki znalazły się na wyposażeniu większości gospodarstw domowych. Upowszechnienie dostępu do energii elektrycznej w znacznym stopniu przyczyniło się do znacznego zbliżenia warunków życia mieszkańców wsi i miast.

\section{Bibliografia}

Białecki T., Wojtaszak A., Osadnictwo polskie jako element procesów migracyjnych na Pomorzu Zachodnim w latach 1945-1948, w: Osadnictwo polskie jako element procesów migracyjnych na Pomorzu Zachodnim w latach 1945-1950. Mity i rzeczywistość, cz. I, red. K. Kozłowski, Szczecin 2002.

Chodyna S., Zarys dziejów elektryfikacji ziemi ostrołęckiej, „Studia Mazowieckie” 2014, nr 1.

Chodyna S., Dzieje elektryfikacji na ziemi pułtuskiej, „Pułtusk” 2014, t. 10.

Elektryka na Pomorzu Zachodnim, red. L. Turek-Kwiatkowska, Szczecin 2006.

Górz B., Elektryfikacja wsi województwa krakowskiego, Kraków 1964.

${ }^{40}$ Szerzej I. Miernik, Powszechna Organizacja Imprez Artystycznych „ARTOS” 1950-1954. Monografia historyczna, Toruń 2005.

${ }^{41}$ M. Machałek, Wybrane aspekty życia kulturalnego mieszkańców wsi pegeerowskich na Pomorzu Zachodnim w latach sześćdziesiatych XX wieku, w: Dzieje wsi pomorskiej, VII Międzynarodowa konferencja naukowa, red. A. Chludziński, R. Gaziński, Dygowo-Szczecin-Pruszcz Gdański 2008, s. 156. 
Historia Kultury Materialnej Polski, t. VI, Od 1870 do 1918 roku, red. B. Baranowski, J. Bartyś, T. Sobczak, Wrocław-Warszawa-Kraków-Gdańsk 1979.

Iwaniak S., Elektryfikacja i mechanizacja wsi kieleckiej (1945-1974), „Studia Kieleckie” Seria Historyczna, 1998, nr 3.

Jarosz D., Polityka władz komunistycznych w Polsce a chłopi, Warszawa 1998.

Jarosz D., Zróżnicowanie kulturowe a zachowania społeczne w PRL (Prolegomena do badań), w: Kultura wysoka, kultura popularna, kultura codzienności w Polsce 1944-1989, red. G. Miernik, Kielce 2010.

Krakowiak S., Historia elektryfikacji wsi, cz. 1, Warszawa 1997.

Kwilecki A., Z badań nad przemianami społeczno-kulturowymi wsi na ziemiach zachodnich, „Przegląd Zachodni” 1961, nr 1.

Łach S., Rolnictwo na Pomorzu Zachodnim w latach 1945-1949, Słupsk 1985.

Machałek M., Wybrane aspekty życia kulturalnego mieszkańców wsi pegeerowskich na Pomorzu Zachodnim w latach sześćdziesiatych XX wieku, w: Dzieje wsi pomorskiej, VII Międzynarodowa konferencja naukowa, red. A. Chludziński, R. Gaziński, Dygowo-Szczecin-Pruszcz Gdański 2008.

Makowski A., Pomorze Zachodnie w polityce gospodarczej Polski w latach 1950-1960, Szczecin 2006.

Romanow A., Warunki życia ludności Gdańska, w: Historia Gdańska, t. IV/1: 1815-1920, red. E. Cieślak, Sopot 1998.

Schmidt H., Die Landwirtschaft von Ostpreussen und Pommern 1914/18-1939, Marburg/ Lahn 1978.

Skodlarski J., Zarys historii gospodarczej Polski, Warszawa 2007.

Stępiński W., Wieś pomorska w drugiej połowie XIX i na początku XX wieku, w: Historia Pomorza, t. IV (1850-1918), cz. I, Ustrój, gospodarka, społeczeństwo, red. S. Salmonowicz, Toruń 2000.

Włodarczyk E., Rozwój urbanistyczny miast pomorskich i ich gospodarka komunalna, w: Historia Pomorza, t. IV (1950-1918), cz. I, Ustrój, gospodarka, społeczeństwo, red. S. Salmonowicz, Toruń 2000.

Trzeci Zjazd Przemysłowy Ziem Odzyskanych, 7-9 IX 1947 r., Warszawa-Łódź 1948.

\section{Abstrakt}

Przed drugą wojną światową poziom upowszechnienia elektryczności na obszarze powojennego Pomorza Zachodniego był znacznie wyższy niż na pozostałych ziemiach polskich. Różnie te były widoczne zwłaszcza na wsi. W wyniku zniszczeń wojennych i powojennych dewastacji nastąpiło znaczne uszczuplenie infrastruktury energetycznej regionu. Mimo stosunkowo dobrej sytuacji wyjściowej, odtworzenie stanu sprzed wojny 
oraz pełna elektryfikacja wsi na Pomorzu Zachodnim wymagały dużych nakładów inwestycyjnych i pokonania trudności technicznych. Omawiany proces miał też wymiar ustrojowo-polityczny. Władze liczyły, że dzięki poprawie warunków życia ludności wiejskiej uzyskają jej poparcie dla socjalistycznych przemian ustrojowych. Za sprawą elektryfikacji łatwiejsze stało się też dotarcie do mieszkańców wsi z przekazem propagandowym.

\title{
Electricity for the Benefit of the Authority and People. Electrification of the villages of Western Pomeranian IN THE FIRST 25 Years after the Second World War
}

\begin{abstract}
Before the Second World War the level of electrification of what was to be Western Pomerania after the war was much higher than in other Polish regions. The differences were even bigger in the rural areas. In the aftermath of the war and as a result of the post-war devastation the energetic infrastructure was reduced even more. In spite of a relatively good initial situation the return to the pre-war state and a full electrification of the villages in Western Pomerania required a lot of capital investment and the task was fraught with difficulties. The whole process had a political dimension, too. The authorities hoped that thanks to the improvement of living conditions of the rural population that section of society would support the socialist regime. Together with electrification it became easier to reach the inhabitants of the rural areas with the propaganda message.
\end{abstract}

